\title{
A Survey of Teachers' and Students' Perspective On E-Learning During Covid-19 in Delhi
}

\author{
Menal Dahiya (D) and Nikita Malik (i)
}

In the unprecedented times today, brought about by the outbreak of the COVID-19 pandemic globally, the education sector has been affected, just like the other industries. Many educational institutes have shut down and suspended traditional physical classroom activities. There has been a shift to the online mode of teaching-learning or 'e-learning,' a web-based digital system that incorporates innovative information and communication technology to facilitate interactive and learner-centred learning environments. The strengths, drawbacks, and opportunities offered by various popular online educational platforms are explored and compared in this study. For the research, data is collected from teachers and students across different courses from various colleges in Delhi through surveys, with questions about their perspectives and experiences concerning online educational platforms. Based on the response, few suggestions concerning the adoption of Google Meet or Microsoft Teams online teaching-learning platform with an easy-to-use interface, the blended model of conducting classes, and improving participation and interaction with students are made. This can contribute to the effective implementation and growth of e-learning approaches in the future.

KEYWORDS: E-Learning, Online Teaching, ICT, COVID-19, Digital Transformation, Education

\section{INTRODUCTION}

All academic activities have shifted to the online state during the ongoing COVID-19 (Coronavirus Disease of 2019) pandemic. This shift has demon-

\author{
Menal Dahiya \\ Dept. of Computer Applications, Maharaja Surajmal Institute, New Delhi, India. \\ Email: menaldahiya@msijanakpuri.com. ORCID: https://orcid.org/0000-0002-5306-2286 \\ Nikita Malik $\square$ \\ Dept. of Computer Applications, Maharaja Surajmal Institute, New Delhi, India. \\ Email: nikitamalik@msijanakpuri.com. ORCID: https://orcid.org/0000-0002-5141-388X
}


strated how technology and the internet have an immense impact on the system and the universal need to access them. The education system's strengths and weaknesses in the face of digitalization are getting revealed. This digital transformation at all levels has acknowledged the integration of ICT (Information and Communication Technology) tools in the modern teaching-learning ecosystem. E-learning-teaching platforms play a significant role during this time. These online platforms support teaching and learning in a real-time digital environment by connecting students and teachers through their own digital devices (personal computers, laptops, or smartphones) using dedicated software with an active internet connection Mishra, Gupta, and Shree (2020); Valverde-Berrocosco, Garrido-Arroyo, Burgos-Videla, and Morales-Cevallos (2020). Such platforms have been designed with extensive features and reliability to offer synchronous and live lectures with instant feedback in a real-time environment. The materials and resources required for teachers or students can also be made available for later offline use. Live video conferencing with active voice support, live chats, the ability to share digital screens with all participants for effective learning and maintaining a digital participant or attendance record are some of the basic features of e-learning platforms (Alameri, Masadeh, Hamadallah, Ismail, \& Fakhouri, 2020).

The primary goal for digital transformation in education is the widespread availability of quality content and educators for learners and students worldwide, anytime and anywhere (Jain, 2019). Reducing the cost for access to resources, providing personalized content to individual learners, digital interactive learning experiences, and improving the learning process are other goals for digital transformation (Ungoti, 2020). Any transformation requires significant changes which take time, resources, investment, and effort to bring forward any favourable outcome, and the same applies to digital transformation in education. As listed on the Digital Marketing Institute (2018) website, a few of these challenges include effort and motivation for adapting to a new platform, digital skills for working with the ICT tools, infrastructure, and budgeting needs. Some digital transformation approaches to resolve these challenges efficiently can be: redefining the available services and resources and making them available in digital formats through advanced digital processes- operation priority; or creating new programs compatible with online platforms and digitizing older programs with physical in-class learning combined with a digital platform- service priority; or a systematic synthesis of both service priority and operation priority approaches simultaneously (Analytics India Magazine, 2020; Digital Marketing Institute, 2018).

In this paper, the strengths, weaknesses, challenges, and opportunities offered by online learning are covered. It discusses the different modes of online teaching and compares the popular e-learning platforms available based 
on their features. The focus of the study is the survey and the observations based on its responses for understanding various aspects of students' and teachers' experiences with online mode of teaching-learning. The study results are crucial because the unexpected lockdowns and work-from-home culture imposed by COVID-19 forced an abrupt shift from traditional classroom teaching to an online teaching mode, and there was no proper guidance for designing course contents to the new requirements. Over the past year, online classes have been conducted at all educational institutes, and learnings from that duration can be integrated into designing a better-suited curriculum and adopting effective teaching practices, as there is still uncertainty with regards to how long the pandemic will last for and the institutes must be prepared. For promoting efficient learning and deciding on the best environments for that, few recommendations have also been made based on observations from the survey.

\section{REVIEW OF Literature}

In their paper, Reyes-Chua et al. focused on implementing e-learning classrooms in HEIs (Higher Education Institutes) in Region IV-A. They conducted an online survey and analysed data using descriptive and documentary analysis. Their findings show that e-learning classrooms are the best option for the country during this pandemic situation. They also proposed student and faculty development workshops, slide presentations on how to use simulations in teaching approaches, and employing free platforms such as Google Meet, Facebook Messenger, Moodle, WeChat, etc. to fulfil the academic needs in times of COVID-19, not just in HEIs, but as a joint effort by all the hierarchy of institutions to make e-learning overall effective (Reyes-Chua et al., 2020).

Dhawan explained the importance of online learning during this pandemic and performed the SWOC analysis of e-learning models. She also briefed about how Ed Tech start-ups entered the Indian market, became famous in the education sector, and are playing a beneficial role in this pandemic as they offer free courses and e-resources for the students. It was recommended for institutes to study all the pros and cons before implementing any e-learning tool (Dhawan, 2020).

Valverde-Berrocosco et al. identified the research topics, most researched modalities, and relevant theories from their systematic literature review using PRISMA protocol and different text mining tools. Their analysis covered three primary nodes- online students, online teachers, and curriculum interactive learning environments Valverde-Berrocosco et al. (2020).

Amin and Sundari explored EFL students' perception of implementing digital platforms such as Cisco WebEx meetings, Google, and WhatsApp mobile 
messenger. They took six criteria: Cisco Webex scored on 73 to 84 of the criteria, Google scored on 74 to 95 criteria, and WhatsApp messenger received favorable agreement on all criteria (Amin \& Sundari, 2020).

Alameri et al. focussed on studying e-learning platforms such as Moodle, Microsoft Teams, and Zoom. They examined students' knowledge about these platforms and their relation to self-study and academic performance. They also listed the advantages and drawbacks of e-learning in quality content analysis and showed the significant effect on students' learning (Alameri et al., 2020).

Soni investigated the global impact of e-learning during the COVID-19 pandemic. The education system has completely and suddenly shifted to electronic learning. He explained the challenges, advantages, and the role of elearning during this time and, through various recommendations, discussed the instructional strategies to improve students' engagement (Soni, 2020).

Mishra et al. detailed the online teaching and learning modes implemented by Mizoram University during the lockdown period in 2020 due to COVID19. They employed both qualitative and quantitative approaches to study the behavior of students and teachers and explained how institutions could use their resources to transform formal education into online education (Mishra et al., 2020).

Lau et al. explained various emerging multimedia technologies that contribute significantly towards e-learning and how these technologies improve students' learning processes. They also focused on the content- type, formulation, etc. to improve the learning effectiveness and experience (Lau, Yen, Li, \& Wah, 2014).

Azlan et al. investigated a case study of Malaysia- feedback of postgraduate medical physics students from the University of Malaya, where Moodle-based SPeCTRUM platform was implemented for carrying out virtual learning activities, were collected. The challenges faced during the 15 weeks duration of this study were discussed, and it was concluded that hybrid learning strategies would remain in the future (Azlan et al., 2020).

Darius et al. explained the present education scenario in the country during the ongoing pandemic, for which they designed a questionnaire for university and college students to determine the effectiveness of the online teaching and learning methods in place. They suggested that animations, online quizzes, presentation slides, and student version software are useful for learning, and e-learning helps students clear their doubts during live sessions by posting their queries as well as assists them in learning topics at their own pace (Darius, Gundabattini, \& Solomon, 2021).

Muthuprasad et al. focused on the self-study preferences of students in agricultural studies during COVID-19, for which they surveyed the students 
online to determine their preference attributes for online classes. Their study concluded that the agricultural education system comprised practical-oriented courses so that the online mode may be shifted to a hybrid mode (Muthuprasad, Aiswarya, Aditya, \& Jha, 2021).

A need for integrating the learnings from the experiences of last year's COVID-19 imposed lockdown in reference to online teaching was required, based on the perspectives of students and teachers in Delhi. In addition, providing aid in making an informed decision about which platform and mode of online teaching-learning to adopt, based on their features and the challenges or benefits they offer, in a compiled way, was also required, for which this study is carried out.

\section{Овjectives Of the Study}

The overall aim of this study is to examine different aspects in e-learning education. The main objective is to determine the experiences and perspectives of faculty and students while using online teaching-learning platforms during the COVID-19 pandemic. Specifically, it determines the engagement of faculty members and participation of students in implementing the online mode of education; discovers the information of various types of platforms online; and explores the problems concerning their use, along with possible solutions and recommendations (Amin \& Sundari, 2020; Mishra et al., 2020; Reyes-Chua et al., 2020).

1) Examining students' general e-learning behaviour and educators' eteaching behaviour- which platform is preferred based on their interactivity, user interface, controls, file, and assignment maintenance.

2) Observing the experiences of students and teachers with the online methods of teaching- the interaction level, attention span, understanding of concepts, doubt resolving, and impact on health.

3) Identifying the challenges and issues encountered during the implementation of online teaching-learning methods as faced by the teachers and students.

4) Discussing how the online teaching-learning platforms are related to selflearning, skill enhancement, and academic performance.

5) Drawing comparisons between current online and previous computing experiences, learning styles, and digital technology attitudes.

6) Suggesting possible solutions and recommendations for the success of online teaching methods. 


\section{Research Methodology}

The work was carried out in three stages:

- The first stage was to carry out a literature review and establish the strengths and weaknesses of online teaching-learning and compare the features offered by the different available popular platforms.

- The second stage was data collection from a sample size of 200 students and 200 professors teaching at different college and courses across Delhi through surveys.

- Finally, conducting a statistical analysis of the received survey responses and suggesting some recommendations for the improved course of action around using ICT in education in the future.

For the second stage, with the help of a literature survey and discussions with peer faculty members, two separate preliminary questionnaires with close-ended questions were prepared for the faculty/teachers and the students. For designing the final questionnaires, the feedback and responses to the MCQs (Multiple Choice Questions) from 10 fellow department teachers of BCA at MSI and currently enrolled second and third-year students (10 each) of undergraduate courses of BCA and B.Com at MSI were considered.

\section{Table 1}

\section{Distribution of the Study Participants.}

\begin{tabular}{|c|c|c|}
\hline Course Wise Count & Age Group & Institute \\
\hline \multicolumn{3}{|c|}{ Students } \\
\hline B. Ed (13) & \multirow{5}{*}{$17-21$ years } & \multirow{5}{*}{$\begin{array}{l}\text { MSI, MSIT, } \\
\text { USIC\&T, IITM, VIPS }\end{array}$} \\
\hline B. Com (43) & & \\
\hline B. Tech (51) & & \\
\hline BCA (64) & & \\
\hline BBA (29) & & \\
\hline \multicolumn{3}{|c|}{ Teachers } \\
\hline B. Ed (9) & \multirow{5}{*}{$27-55$ years } & \multirow{5}{*}{$\begin{array}{l}\text { MSI, MSIT, MRU, } \\
\text { USICT, AIACTR, } \\
\text { IITM, HMR }\end{array}$} \\
\hline B. Com (18) & & \\
\hline B. Tech (67) & & \\
\hline BCA (43) & & \\
\hline BBA (63) & & \\
\hline
\end{tabular}

The link for the survey Google forms was shared with a few initial study participants through WhatsApp and email and circulated with others using the snowball sampling/ chain-referral method. The forms were closed for 
responses once 200 responses each were received from the teachers and the students. The distribution of the students and the teaching faculty who participated in the study are shown in Table 1 . The questionnaire comprised 18 questions, and at least 3-4 questions were directed towards providing responses for each of the specified objectives.

\section{SWOC Analysis of ONLINE Learning}

With almost the entire world in a quarantine situation due to the global pandemic, schools, colleges, universities, and other educational institutes have been most affected. Online teaching/learning platforms use various pedagogical approaches to tackle new market conditions and help the teachers/students to adapt to the changing situations. The e-learning platforms provide a lot of flexibility, affordability, and accessibility. However, it can sometimes be challenging for students and teachers due to the various problems associated with modern technology (Reyes-Chua et al., 2020). COVID-19 pandemic situation pushed the academic institutions for an overnight shift from traditional classroom teaching to e-classroom methods while maintaining quality education (Alameri et al., 2020; Soni, 2020).

Similar situations had arisen in the past, where natural disasters had disrupted traditional teaching-learning methods like an earthquake in 2011, in which both the Christchurch and the University of Canterbury collapsed and had to resort to ICT-based virtual classes to continue operating (Todorova \& Bjorn-Andersen, 2011) or when at New Orleans, Southern University had to convert to an e-learning campus offering online courses to displaced students post the violent hurricane (Omar, Liu, \& Koong, 2008).

These incidents/natural disasters have disturbed the flow of educational processes and led to online education. E-learning/teaching education is not a new concept for us, but it is not an option due to this pandemic and rather emerged as the necessity of the hour. All the colleges, schools, and institutions face a tough time and seek the help of online learning so that students or any learner have not been affected by this isolation period. There are a few ways where online platforms can outperform traditional classroom teaching practices (Broderick, n.d.; Sammer, 2020; Ungoti, 2020).

- Online platforms are not bound by geography if the basic requirements, i.e., an active internet connection and a computer device, exist.

- Such platforms can be more engaging as they can utilize multimedia formats with attention-grabbing material and explain concepts in more vivid and simplistic formats.

- In many ways, feedback can be faster and more frequent in online learning 
platforms as educators can take more frequent assessments and monitor their student's competence, so learning gaps can be identified before it is too late.

- There is no doubt that such online platforms can be much cheaper than regular offline courses, and, in many cases, online courses can hold the same value as their offline counterparts.

- It is no secret that online platforms are much more relaxed and less tense, and informal than regular classrooms and can have more frequent breaks so students can keep their concentration for more extended periods. It is much less exhausting, and students can have much more time on their hands as they do not have to repeat the daily tasks to get to their offline classes and are less tired and more productive the entire day.

- The educators can also be much more available to their students as they can connect easily anytime through these platforms, and the learning gaps can be hurdled much smoothly and swiftly.

Figure 1 depicts the identified strengths, weaknesses, opportunities, and challenges (SWOC) of the online learning process (Dhawan, 2020):

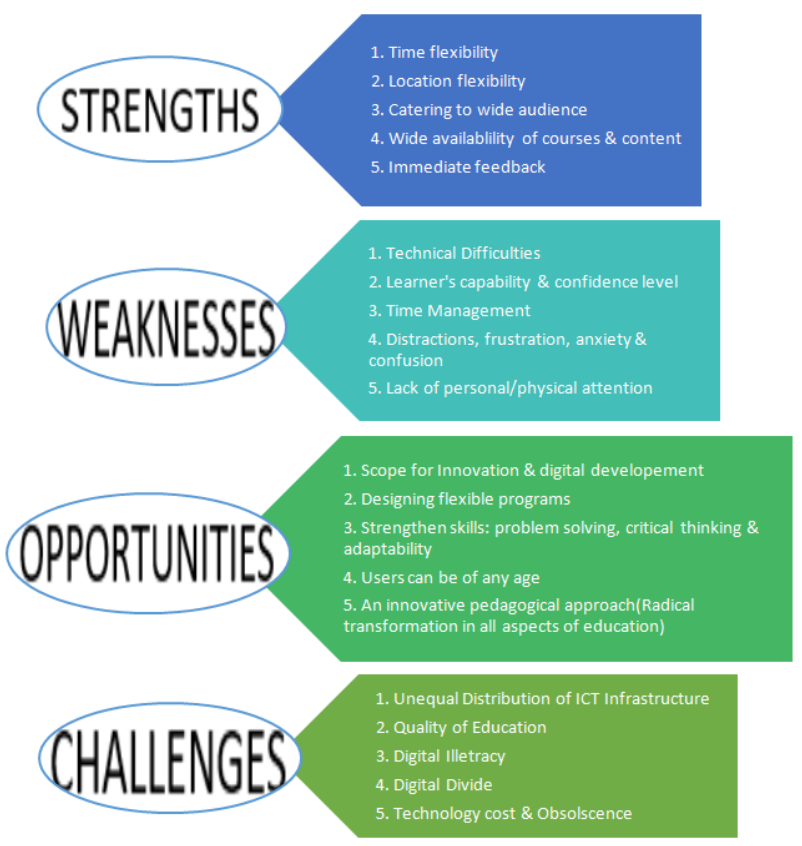

Figure 1. SWOC of Online Teaching/Learning.

Strengths: A plethora of available online platforms have started gaining 
popularity in India. These platforms provide various user-friendly features, adding to the strength of online learning/teaching methods. They play an effective and efficient role for both educators and learners. Besides taking online video lectures, educators can use pre-recorded videos for the study material or simple documents, presentations, etc., to provide e-resources for students. Further, the videos can also be compressed for easy viewing or saved for later use. The anytime-anywhere facility of e-learning is beneficial for all and adopting the modern ICT technologies as a part of the teaching-learning paradigm promotes innovation in education (Mark \& Semaan, 2008).

Weaknesses: The only major weakness of online platforms is the absence of direct communication between students and teachers. In India, teacherstudent relation is like a parent-child relation, and their communication and attachment acts as a solution to many problems. All students are not similar in capabilities and technological usage, and some are not comfortable with the online mode of learning (Favale, Soro, Trevisan, Drago, \& Mellia, 2020). The same weaknesses apply to educators; all teachers are not well equipped or skilled to use the latest technologies. These issues can create confusion and add to frustration.

Opportunities: Online teaching-learning platforms offer many opportunities to the teachers as well as students. Educators can increase their ICT skills, upgrade their involvement in academic sessions, provide a flexible environment to the students, and help develop pedagogy approaches. In India, before the COVID-19 situation, online learning represented distance learning or parttime courses from open universities, but now, most academic institutions have switched to this model (Soni, 2020).

Challenges: Online learners, as well as educators, also face few challenges. It was challenging for schools and universities to switch to online teaching practices abruptly and so was for students to adapt to the usage of the online platforms for learning. It is also challenging to keep the students engaged, interested, and attentive while managing their curriculum correctly. The government, too, had to take up the challenge of introducing and revising its educational policies in keeping with the current needs while maintaining the appropriate quality, controlling the quantity, the content of the curriculum, and the availability of e-resources (Affouneh, Salha, \& Khlaif, 2020). Unavailability of internet resources, lack of proper knowledge of modern technology, and various other significant aspects are the hurdles surrounding online modes of teaching-learning by teachers and students (Dhawan, 2020). 


\section{E-Learning Modes and Platforms: Comparison}

The integration of multimedia technologies, such as games, communication technologies, and social networks, has become a key element in e-learning technology development. The various media and communication tools help improve user interaction and content visualization (Lau et al., 2014).

The definition of online learning includes experiences in both the synchronous and asynchronous environments for the independent students to be anywhere to learn and interact with the teachers through various devices with internet access (Singh \& Thurman, 1988). Figure 2 presents these two modes of e-learning delivery, i.e., synchronous, and asynchronous.

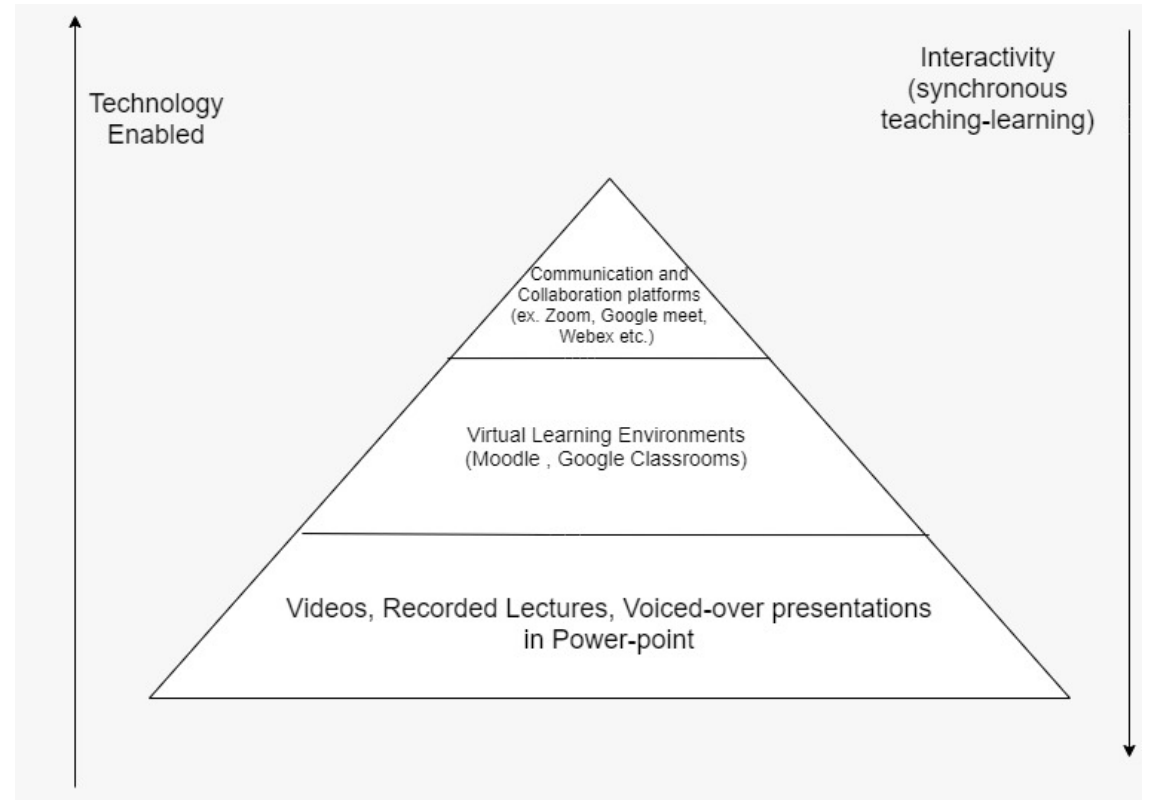

Figure 2. Modes of Delivery for E-Learning (Azlan et al., 2020).

Synchronous delivery resembles a classroom where interaction is not physical but virtual and real-time, with immediate feedback. It uses videoconferencing platforms such as Microsoft Teams (MS Teams), Zoom, Google Meet, Cisco Webex, etc., and can conduct live lectures, discussions, or quizzes (Azlan et al., 2020). Social interaction in this delivery mode creates many opportunities, but the main issue encountered in this mode is the dependability on internet connections' quality, as it can disrupt the flow and the quality of understanding of the delivered lecture (Dhawan, 2020). Whereas in asynchronous delivery, the interaction between educators and students is not 
instant, and the learning content is available at different times, not as live lectures. Teaching and learning activities include pre-recorded lecture videos or slides or offline assignments, using YouTube, Google classrooms, WhatsApp groups, etc. The issue with this delivery mode is the lack of interaction that may cause difficulty understanding concepts and self-discipline (Azlan et al., 2020).

To create a curriculum based on blended learning, both the learning styles can be combined in the teaching environment. This learning style integrates e-resources in a traditional classroom setup, establishing options for creating an effective learning system based on synchronous or asynchronous options whenever required. An LMS (Learning Management System) can offer a blended environment and increase engaged learning through scheduled assignments and video conference-based inquiries, allowing educators to track progress while facilitating student interaction and freedom (Amin \& Sundari, 2020).

Several e-learning platforms have popularized since the spread of COVID19. A careful comparative analysis based on the users' needs, features offered, and the involved maintenance cost should be done before their adoption. Accordingly, the teachers' and students' perception of each varies (Alameri et al., 2020; Reyes-Chua et al., 2020). Table 2 shows a comparison between the capabilities of a few of these platforms.

Table 2

Comparison of Few Popular Synchronous E-Teaching/Learning Platforms.

\begin{tabular}{lccccc}
\hline FEATURES & $\begin{array}{c}\text { CISCO } \\
\text { WEBEX }\end{array}$ & $\begin{array}{c}\text { GOOGLE } \\
\text { MEET }\end{array}$ & ZOOM & $\begin{array}{c}\text { GOTO } \\
\text { MEET- } \\
\text { INGS }\end{array}$ & $\begin{array}{c}\text { MS } \\
\text { TEAMS }\end{array}$ \\
\hline FREE & $\begin{array}{c}\text { Free } \\
\text { basic } \\
\text { plan }\end{array}$ & $\begin{array}{c}\text { Free } \\
\text { basic } \\
\text { plan }\end{array}$ & $\begin{array}{c}\text { Free } \\
\text { basic } \\
\text { plan }\end{array}$ & $\begin{array}{c}\text { Free } \\
\text { basic } \\
\text { plan } 30 \\
\text { days } \\
\text { trail }\end{array}$ & $\begin{array}{c}\text { Free basic } \\
\text { plan(No } \\
\text { additional } \\
\text { cost for } \\
\text { Microsoft } \\
365 \text { users })\end{array}$ \\
\hline $\begin{array}{l}\text { NO. OF FREE } \\
\text { USERS }\end{array}$ & 100 & 150 & 100 & 3 & 250 \\
\hline
\end{tabular}


211 | Menal Dahiya and Nikita Malik

Table 2 continued

\begin{tabular}{|c|c|c|c|c|c|}
\hline FEATURES & $\begin{array}{r}\text { CISCO } \\
\text { WEBEX }\end{array}$ & $\begin{array}{l}\text { GOOGLE } \\
\text { MEET }\end{array}$ & ZOOM & $\begin{array}{l}\text { GOTO } \\
\text { MEET- } \\
\text { INGS }\end{array}$ & $\begin{array}{c}\text { MS } \\
\text { TEAMS }\end{array}$ \\
\hline $\begin{array}{l}\text { FREE CON- } \\
\text { FERENCES }\end{array}$ & $\begin{array}{l}50 \text { mins } \\
\text { limit }\end{array}$ & $\begin{array}{l}60 \text { mins } \\
\text { per } \\
\text { meeting }\end{array}$ & $\begin{array}{l}\text { Unlimite } \\
\text { 1:1 } 40 \\
\text { mins } \\
\text { for } \\
\text { Group } \\
\text { Calls }\end{array}$ & $\begin{array}{l}\text { d } 40 \text { mins } \\
\text { limit }\end{array}$ & No limit \\
\hline $\begin{array}{l}\text { UPGRADE } \\
\text { COST }\end{array}$ & \$89/Month & \$6/Month & $\$ 14.99$ & \$49/Mon & \$20/user/n \\
\hline $\begin{array}{l}\text { SCREEN } \\
\text { SHARING }\end{array}$ & Yes & Yes & Yes & Yes & Yes \\
\hline $\begin{array}{l}\text { VIDEOCON- } \\
\text { FERENCING }\end{array}$ & Yes & Yes & Yes & Yes & Yes \\
\hline $\begin{array}{l}\text { PRESENTATION } \\
\text { STREAM- } \\
\text { ING }\end{array}$ & N Yes & Yes & Yes & Yes & Yes \\
\hline $\begin{array}{l}\text { RECORD \& } \\
\text { PLAYBACK }\end{array}$ & $\begin{array}{l}\text { For Paid } \\
\text { Plans }\end{array}$ & $\begin{array}{c}\text { For Paid } \\
\text { Plans }\end{array}$ & $\begin{array}{l}\text { For } \\
\text { Paid } \\
\text { Plans }\end{array}$ & $\begin{array}{l}\text { For Paid } \\
\text { Plans }\end{array}$ & $\begin{array}{l}\text { For Paid } \\
\text { Plans }\end{array}$ \\
\hline $\begin{array}{l}\text { E-HAND } \\
\text { RAISING }\end{array}$ & Yes & Yes & Yes & Yes & Yes \\
\hline $\begin{array}{l}\text { TWO-WAY } \\
\text { AUDIO \& } \\
\text { VIDEO }\end{array}$ & Yes & Yes & Yes & Yes & Yes \\
\hline $\begin{array}{l}\text { CHAT } \\
\text { MAX. VIDEO } \\
\text { PARTICI- } \\
\text { PANTS }\end{array}$ & $\begin{array}{c}\text { Yes } \\
8-100\end{array}$ & $\begin{array}{l}\text { Yes } \\
100\end{array}$ & $\begin{array}{c}\text { Yes } \\
25\end{array}$ & $\begin{array}{c}\text { Yes } \\
25\end{array}$ & $\begin{array}{l}\text { Yes } \\
4-9\end{array}$ \\
\hline ANNOTATION & Yes & Yes & Yes & Yes & No \\
\hline $\begin{array}{l}\text { REMOTE } \\
\text { CONTROL }\end{array}$ & Yes & No & Yes & Yes & No \\
\hline $\begin{array}{l}\text { MOBILE } \\
\text { SUPPORT }\end{array}$ & $\begin{array}{l}\text { Android, } \\
\text { iOS }\end{array}$ & $\begin{array}{l}\text { Android, } \\
\text { iOS }\end{array}$ & $\begin{array}{l}\text { Android } \\
\text { iOS }\end{array}$ & $\begin{array}{l}\text { Android, } \\
\text { iOS }\end{array}$ & $\begin{array}{l}\text { Android, } \\
\text { iOS }\end{array}$ \\
\hline
\end{tabular}

Continued on next page 
Table 2 continued

\begin{tabular}{|c|c|c|c|c|c|}
\hline FEATURES & $\begin{array}{l}\text { CISCO } \\
\text { WEBEX }\end{array}$ & $\begin{array}{l}\text { GOOGLE } \\
\text { MEET }\end{array}$ & ZOOM & $\begin{array}{c}\text { GOTO } \\
\text { MEET- } \\
\text { INGS }\end{array}$ & $\begin{array}{c}\text { MS } \\
\text { TEAMS }\end{array}$ \\
\hline ACCESS & $\begin{array}{l}\text { Web } \\
\text { Browser } \\
\text { or Down- } \\
\text { load } \\
\text { App }\end{array}$ & $\begin{array}{c}\text { Web } \\
\text { Browser } \\
\text { or } \\
\text { Down- } \\
\text { load } \\
\text { App }\end{array}$ & $\begin{array}{c}\text { Web } \\
\text { Browser } \\
\text { or } \\
\text { Down- } \\
\text { load } \\
\text { App }\end{array}$ & $\begin{array}{c}\text { Web } \\
\text { Browser } \\
\text { or } \\
\text { Down- } \\
\text { load } \\
\text { App }\end{array}$ & $\begin{array}{c}\text { Web } \\
\text { Browser or } \\
\text { Download } \\
\text { App }\end{array}$ \\
\hline GRID VIEW & 25 people & $\begin{array}{c}16 \\
\text { people }\end{array}$ & $\begin{array}{c}49 \\
\text { people }\end{array}$ & 4 people & 4 people \\
\hline $\begin{array}{l}\text { JOIN } \\
\text { WITHOUT } \\
\text { ACCOUNT }\end{array}$ & Yes & No & Yes & Yes & No \\
\hline REPORTS & Yes & Yes & Yes & No & $\begin{array}{c}\text { Yes(But } \\
\text { Basic) }\end{array}$ \\
\hline POLLING & Yes & No & No & No & No \\
\hline WHITEBOARD & Yes & $\begin{array}{l}\text { Yes (but } \\
\text { not in } \\
\text { built) }\end{array}$ & Yes & Yes & Yes \\
\hline
\end{tabular}

As presented in Table 2:

- MS Teams has the highest number of support for 250 users at a time.

- MS Teams has an unlimited call time, whereas Zoom has the shortest time of 40 minutes for group calls.

- Zoom has the cheapest upgrade cost from an objective perspective, whereas Cisco Webex has the highest upgrade cost, but depending on the user base, MS Teams may have the highest upgrade cost as the cost relies on the number of users.

- All platforms have the basic features of screen sharing, two-way video and audio, live chat, video conferencing, and presentation sharing and support a record feature.

- Cisco Webex has the maximum number of video participants of 100, whereas MS Teams has the minimum number of maximum participants of 9 .

- Apart from MS Teams, every platform supports annotation, remote control, and support for joining without accounts.

- All platforms are readily available on all OS platforms (Windows, Mac OS, Android, and IOS). 


\section{3 | Menal Dahiya and Nikita Malik}

- Zoom supports the maximum number of people in a grid view of 49 people, and MS Teams and GoToMeetings support the least number of maximum people of 4 .

- All platforms have a report feature except for GoToMeeting.

- Except for Cisco Webex, no other platform supports a polling feature.

- All platforms support a whiteboard feature.

\section{AnAlysis AND Discussion of Results}

In the following section, the survey results have been statistically analysed and interpreted through Figure 3 to Figure 8, and it is discussed how the objectives for this study are determined.

Examining the General E-Learning Behaviour of Students and E-Teaching Behaviour of Teachers:

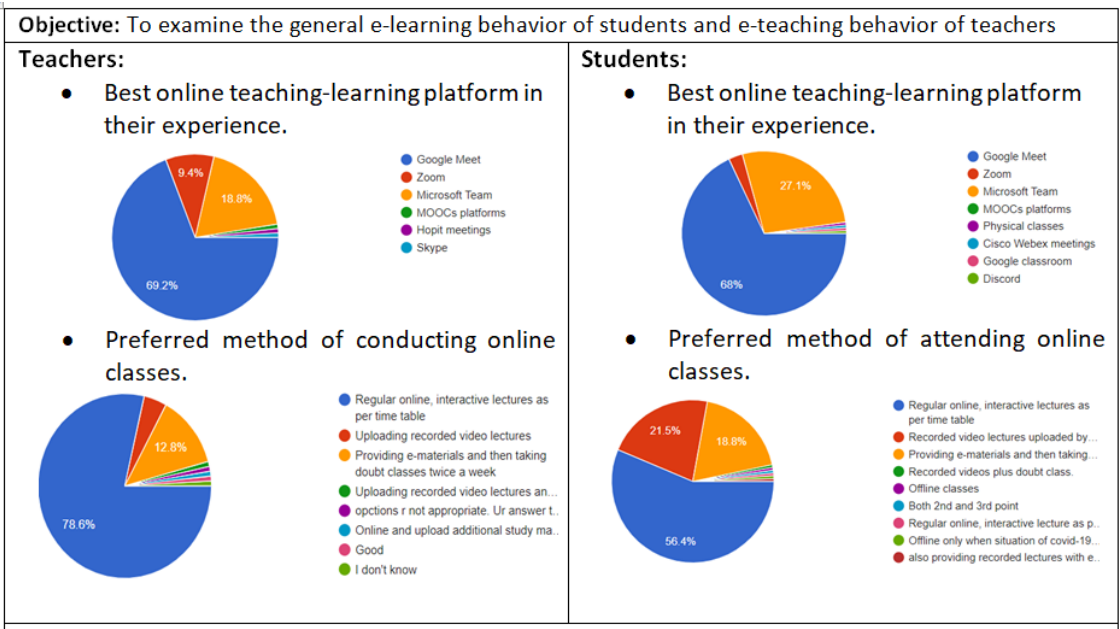

\section{Figure 3. Survey Results Towards Examining}

According to the survey, the best online teaching-learning method selected by the teachers and students is Google Meet. In the present scenario, where multiple platforms are available to choose from, more than half of the surveyed teachers and students chose Google Meet, followed by Microsoft Teams and Zoom as the popular alternatives. Around 69\% of teachers preferred to use Google Meet because of its ease of use, and since many of them had used Google Classrooms before, so it was easier to generate Google Meet links from the classroom itself and not switch to another platform. Teachers also chose 
MS Teams because they feel that it offers better controls over class, interactive announcement posts, and proper assignment and files' maintenance. In online classes, around $79 \%$ of students prefer regular interactive classes as per timetable, while few students chose the reverse classroom method, i.e., providing them with e-resources and then conducting class to clarify doubts. Most teachers $(56 \%)$ also share the same preference for conducting regular interactive classes, while around $21 \%$ and $19 \%$ are inclined to provide video lectures or electronic study materials for students to study at their convenience and then hold classes for doubts.

Observing the Experiences of Students as Well as Teachers With Online Methods of Teaching:

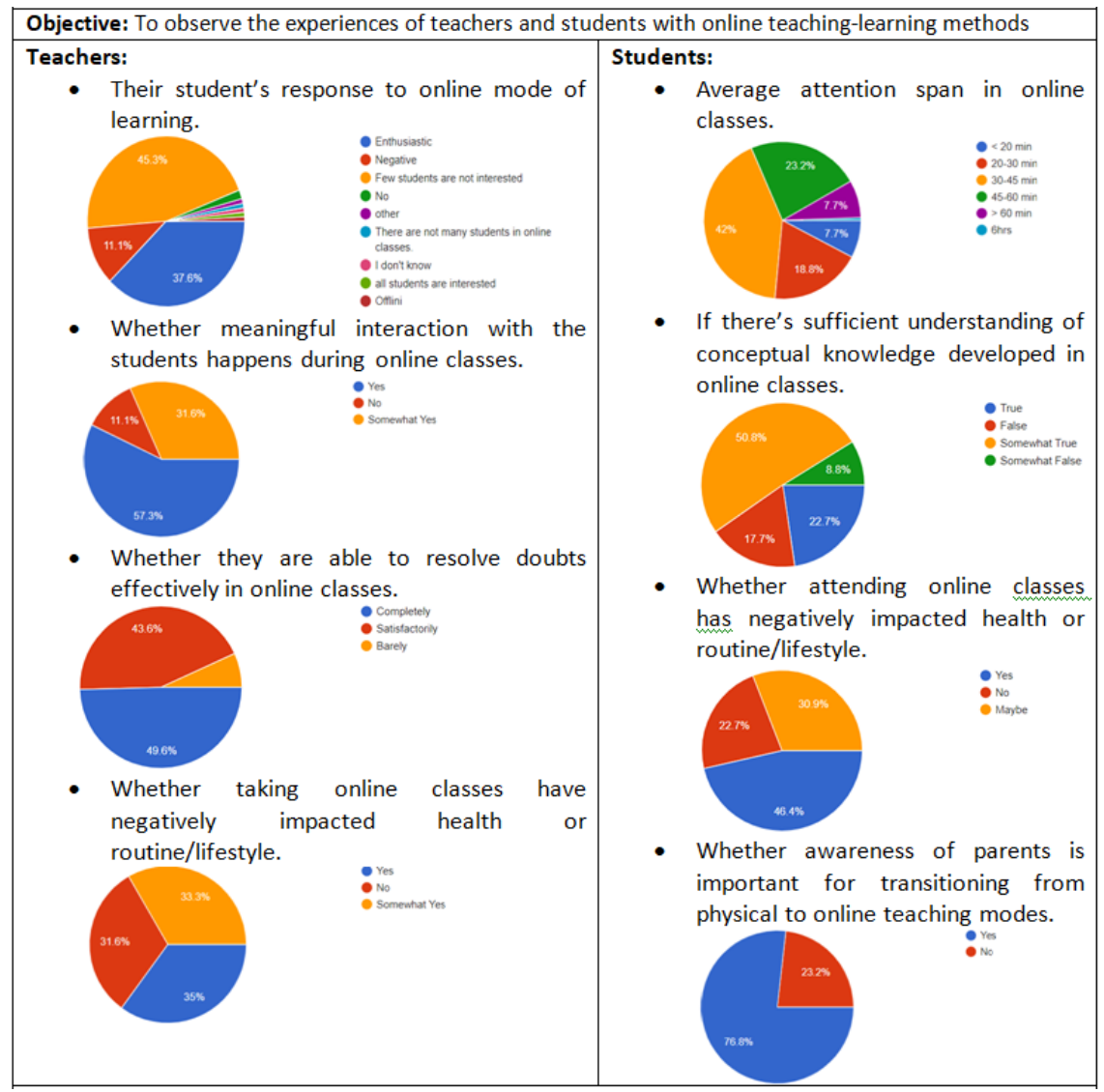

Figure 4. Survey Results Towards Observing the Experiences of Students as Well as Teachers with Online Methods of Teaching. 
The students' experience with online learning has been positive on an average, wherein they can develop a sufficient understanding of the taught concepts. Most teachers also believe that they can explain concepts and resolve any doubts that arise during online classes and the interaction with students through virtual classes is meaningful. However, just as in traditional classrooms, few students are not interested in attending classes, and the average span of attention for students during online classes has dropped down to 30 to 45 minutes. Also, most of the students (46\%) and teachers (67\%) agreed that the online mode of teaching-learning had negatively impacted their health and lifestyle.

Identifying The Challenges and Issues Encountered During the Implementation of Online Teaching-Learning Methods as Faced by the Teachers and Students:

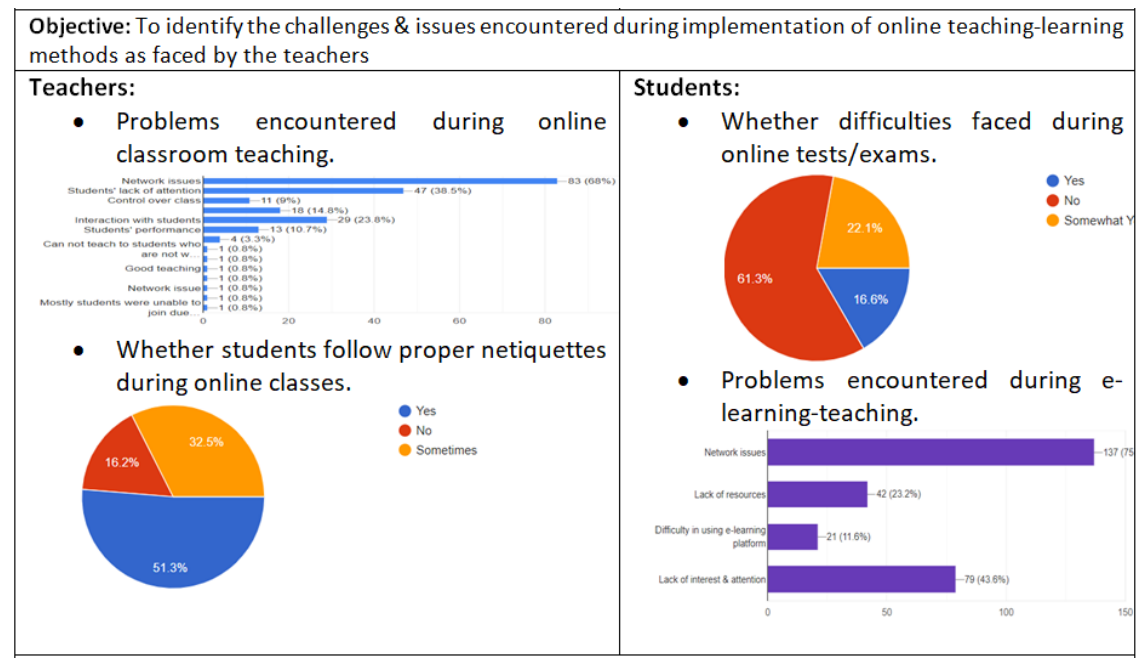

Figure 5. Survey Results Towards Identifying the Challenges and Issues Encountered During the Implementation of Online Teaching-Learning Methods as Faced by the Teachers and Students.

Besides the advantages of the different e-teaching/learning platforms, the students and teachers also faced a few drawbacks or challenges. The major common issue was network connectivity ( $83 \%$ teachers and $75 \%$ students), i.e., poor internet connection and lack of infrastructure for effective platform usage. Additionally, teachers (47\%) observed a lack of attention span in the students and relatively less fruitful interaction with the students in online teaching than traditional classroom teaching. $79 \%$ of students also felt some drop in their interest and attention span towards online teaching methods. Few of them 
(22\%) also faced issues during online tests conducted by teachers, wherein teachers also believe that assessing actual student performance by such online means is not satisfactory. Teachers also complained of a lack of proper online etiquette (netiquettes) by a specific set of students to create disturbances in the online class.

Discussing How the Online Teaching-Learning Platforms are Related to Self-Learning, Skill Enhancement and Academic Performance:

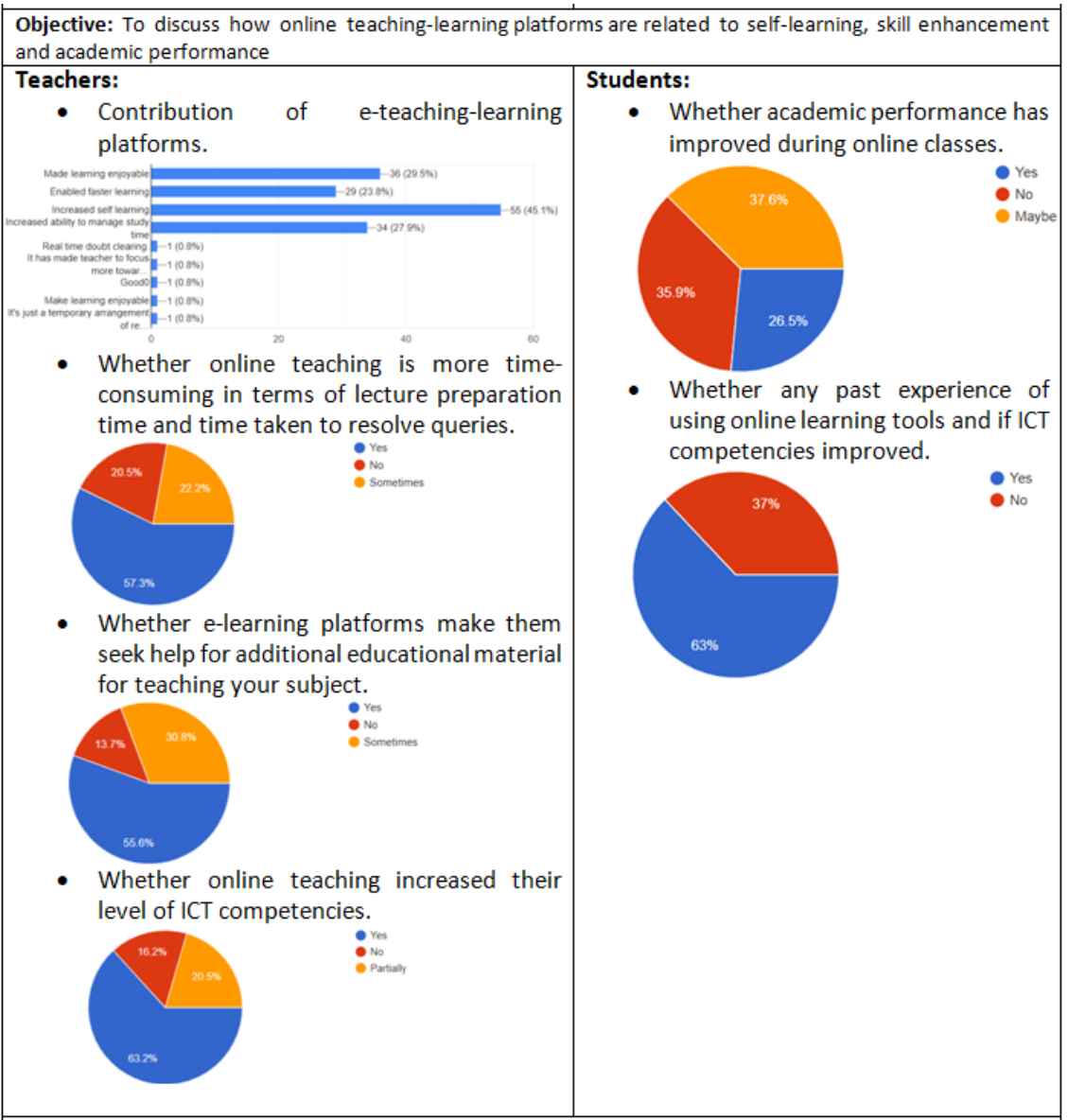

Figure 6. Survey Results Towards Discussing How the Online Teaching-Learning Platforms are Related to Self-Learning, Skill Enhancement and Academic Performance.

According to the teachers, the online mode of teaching has contributed to making learning a somewhat more enjoyable process for the students by 
introducing gamification techniques and online MCQ-based assessments from the comfort of their homes. $56 \%$ of teachers also believe that it has increased self-learning in everyone and enforced more management of study time. 57\% of teachers say that the time required for preparing their lectures, assignments, and assessment methods takes more time as they seek help from additional educational materials and use ICT tools. This process has further improved the ICT competency levels of over $63 \%$ of teachers. The students (around $63 \%$ ) have improved their skills online; however, their academic performance has not improved much throughout the online teaching-learning process.

Drawing Comparisons Between Current Online and Previous Computing Experiences, Learning Styles and Digital Technology Attitudes:

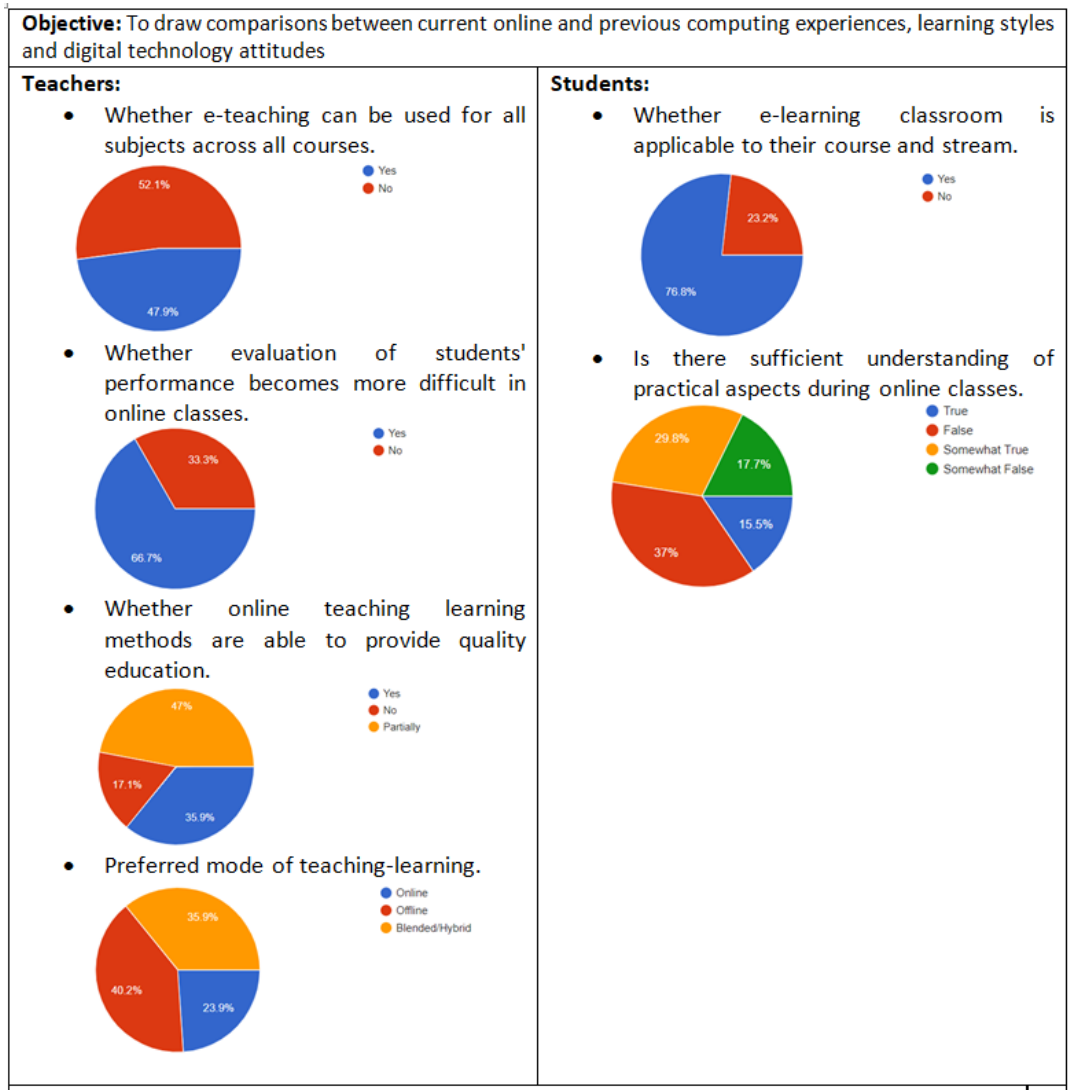

Figure 7. Survey Results Towards Drawing Comparisons Between Current Online and Previous Computing Experiences, Learning Styles and Digital Technology Attitudes. 
According to the survey, $77 \%$ of students believe that online teachinglearning applies to their course and stream of study, but most teachers (52\%) feel that online teaching is not a viable option across all courses, especially life sciences. As far as the practical concepts are concerned, only $46 \%$ of the students agree to develop a sufficient understanding through online classes. Most of the teachers (47\%) believe only partially that quality education can be imparted solely through online teaching methods, and $40 \%$ of them prefer a blended or hybrid mode of teaching instead of just online. As high as $67 \%$ of teachers are of the opinion that accurate evaluation of students' performance, one of the essential aspects of teaching-learning, is much more difficult in online mode.

\section{Suggesting Possible Solutions and Recommendations for the Success of} Online Teaching Methods:

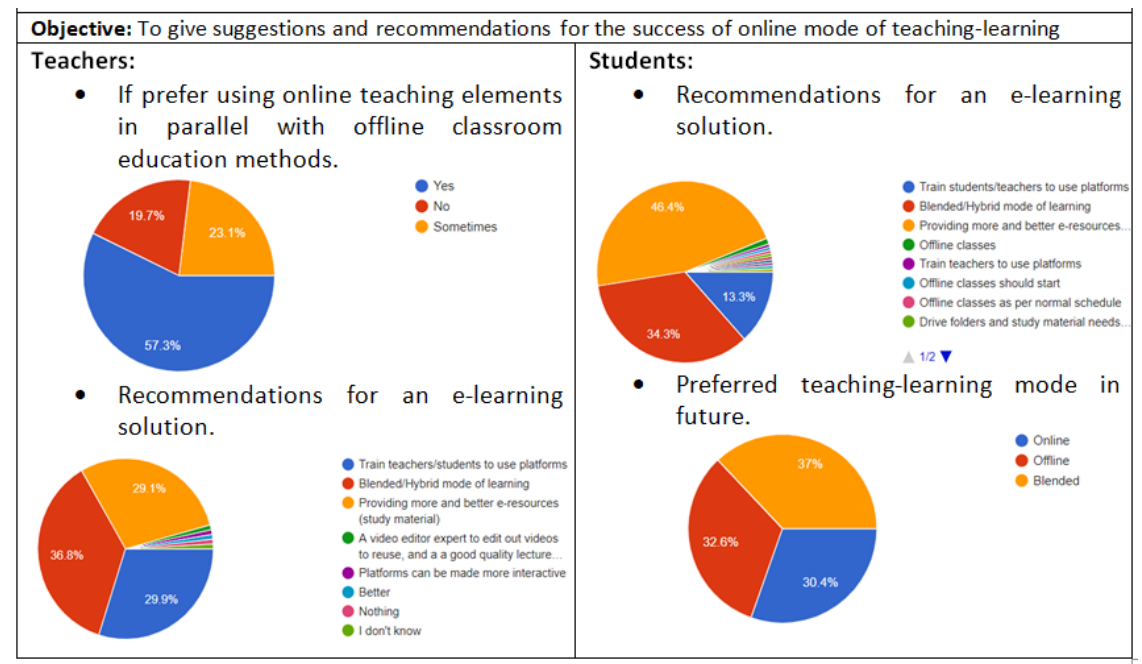

Figure 8. Survey Results Towards Suggesting Possible Solutions and Recommendations for the Success of Online Teaching Methods.

The hybrid teaching-learning mode is preferred by teachers and students alike. $57 \%$ of teachers are inclined towards using online teaching elements in parallel with offline classroom methods, and $37 \%$ of students also prefer the blended mode of teaching-learning. Towards improved e-learning, some solutions, as recommended by teachers and students, are- providing proper training to teachers/students for using the different online platforms, preparing and providing better study material (e-resources), followed by synchronous teaching methods. 


\section{RECOMMENDATIONS}

Some recommendations based on the survey result analysis are:

- Google Meet and Google Classroom, or Microsoft Teams should be preferably adopted as the platforms for conducting online classes as most educators and students are comfortable with their user interface and the features and controls, they provide. Moreover, they are available freely for minimal cost plans. They offer both the advantages of synchronous and asynchronous teaching modes through their live video conferencing and classwork/assignment/quiz sharing features.

- Parents, students, and teachers who are new to ICT should be provided with proper training to be comfortable using the platforms and enjoy and avail full benefits from the e-teaching/learning process.

- Flipped classroom style of blended teaching-learning should be adopted. As e-learning involves much self-study, good quality e-resources should be prepared and provided to students by the educators, and the same can later be discussed further in detail with a focus on problem-solving through interactive online classes. This way, the online classes will be more interesting and engaging for the students.

- Furthermore, blended or hybrid teaching-learning practices concerning conducting both physical/traditional offline and online classes should be implemented wherever possible. Students should meet the teacher in person from time to time to get doubts clarified, or once a week, practical demonstrations can be conducted in a traditional offline classroom setting for developing a better overall understanding of concepts and practical aspects. This will also address students' low attention span in online classes as the offline classes will give them a break from their screen time.

\section{Conclusions}

E-learning methods offer to provide inclusive and effective education in times of crisis. These methods are here to stay and will continue to be used even after the COVID-19 pandemic situation. This study explored the strengths and the opportunities created by e-teaching and learning environments in today's scenario and discussed the challenges faced in their implementation. It also identified the different modes of online learning and compared a few popular supporting platforms based on their offered features. Data collected from surveying a sample of educators and learners from various Delhi colleges were analysed statistically. Few recommendations concerning adopting online teachinglearning platforms with an easy-to-use interface, the blended mode of conducting classes, and improving participation and interaction with students 
are made. The outcomes of this study can enable the future course of action towards the implementation and growth of technologies employed in the education sector.

\section{REFERENCES}

Affouneh, S., Salha, S., \& Khlaif, Z. N. (2020). Designing quality e-learning environments for emergency remote teaching in coronavirus crisis. Interdisciplinary Journal of Virtual Learning in Medical Sciences, 11(2), 135-137.

Alameri, J., Masadeh, R., Hamadallah, E., Ismail, H. B., \& Fakhouri, H. N. (2020). Students' Perceptions of E-learning platforms (Moodle, Microsoft Teams and Zoom platforms) in The University of Jordan Education and its Relation to self-study and Academic Achievement During COVID-19 pandemic. Advanced Research and Studies Journal, 11(5), 21-33.

Amin, F. M., \& Sundari, H. (2020). EFL students' preferences on digital platforms during emergency remote teaching: Video Conference, LMS, or Messenger Application? . Studies in English Language and Education, 7(2), 362-378. https:/ / doi.org/10.24815/siele.v7i2.16929

Analytics India Magazine. (2020). Adoption Of E-learning During Crises \& Lockdowns. Retrieved from https:/ / analyticsindiamag.com/ adoption-of-e-learning-during-crises-lockdowns /

Azlan, C. A., Wong, J. H., Tan, L. K., Huri, M. S., Ung, N. M., Pallath, V., ... Ng, K. H. (2020). Teaching and learning of postgraduate medical physics using Internet-based e-learning during the COVID-19 pandemic-A case study from Malaysia. Physica Medica, 80, 10-16. https://doi.org/10.1016/j.ejmp.2020.10.002

Broderick, T. (n.d.). 7 Advantages to Taking Online Classes. Retrieved from https://oedb.org/ilibrarian/10-advantages-to-taking-online -classes/\#: :text=Although\%20online\%20courses\%20maintain\% 20the

Darius, P. S. H., Gundabattini, E., \& Solomon, D. G. (2021). A Survey on the Effectiveness of Online Teaching-Learning Methods for University and College Students. Journal of The Institution of Engineers (India): Series B, 1-10. https://doi.org/10.1007/s40031-021-00581-x

Dhawan, S. (2020). Online learning: A panacea in the time of COVID-19 crisis. Journal of Educational Technology Systems, 49(1), 5-22. https:// doi.org/10.1177/0047239520934018

Digital Marketing Institute. (2018). How to Bring Digital Transformation to Education. Retrieved from https:/ / digitalmarketinginstitute.com/ blog/how-to-bring-digital-transformation-to-education 
Favale, T., Soro, F., Trevisan, M., Drago, I., \& Mellia, M. (2020). Campus traffic and e-Learning during COVID-19 pandemic. Computer Networks, 176, 107290. https:/ / doi.org/10.1016/jcomnet.2020.107290

Jain, R. (2019). What Is The Need Of Digital Transformation. Retrieved from https://www.asmaindia.in/blog/need-digital-transformation -education/

Lau, R. W., Yen, N. Y., Li, F., \& Wah, B. (2014). Recent development in multimedia e-learning technologies. World Wide Web, 17(2), 189-198. https://doi.org/10.1007/s11280-013-0206-8

Mark, G., \& Semaan, B. (2008). Resilience in Collaboration: Technology as a Resource for New Patterns of Action. In and others (Ed.), Acm conference on computer supported cooperative work (p. 137-146).

Mishra, L., Gupta, T., \& Shree, A. (2020). Online teaching-learning in higher education during lockdown period of COVID-19 pandemic. International Journal of Educational Research Open, 1, 100012. https://doi.org/10.1016/j.ijedro.2020.100012

Muthuprasad, T., Aiswarya, S., Aditya, K. S., \& Jha, G. K. (2021). Students' perception and preference for online education in India during COVID-19 pandemic. Social Sciences \& Humanities Open, 3(1), 100101. https://doi.org/10.1016/j.ssaho.2020.100101

Omar, A., Liu, L. C., \& Koong, K. S. (2008). From disaster recovery to mobile learning: A case study. International Journal of Mobile Learning and Organisation, 2(1), 4-17. https:// doi.org/10.1504/IJMLO.2008.018714

Reyes-Chua, E., Sibbaluca, B. G., Miranda, R. D., Palmario, G. B., Moreno, R. P., \& Solon, J. P. (2020). The status of the implementation of the elearning classroom in selected higher education institutions in region IV-A amidst the covid-19 crisis. Journal of Critical Reviews, 7(11), 253258. https://doi.org/10.31838/jcr.07.11.41

Sammer, T. (2020). 8 Reasons Why Online Education is Better than Traditional. Retrieved from https://www.nitrocollege.com/blog/ online-college/why-online-education-better

Singh, V., \& Thurman, A. (1988). How many ways can we define online learning? A systematic literature review of definitions of online learning. American Journal of Distance Education, 33(4), 289-306.

Soni, V. D. (2020). Global Impact of E-learning during COVID 19. SSRN. https:// doi.org/10.2139/ssrn.3630073

Todorova, N., \& Bjorn-Andersen, N. (2011). University learning in times of crisis: The role of IT. Accounting Education, 20(6), 597-599. https:/ / doi.org/10.1080/09639284.2011.632913

Ungoti. (2020). 11 Objectives of Digital Transformation. Retrieved from https://ungoti.com/blog/objectives-of-digital-transformation/

Valverde-Berrocosco, J., Garrido-Arroyo, M. D., Burgos-Videla, C., \& 
Teachers' And Students' Perspective on E-Learning | 222 Morales-Cevallos, M. B. (2020). Trends in Educational Research about e-Learning: A systematic literature review (2009-2018). Sustainability, 12(12), 5153. https://doi.org/10.3390/su12125153 